Article

\title{
Patterns of Conflict and Mobilization: Mapping Interest Group Activity in EU Legislative Policymaking
}

\author{
Arndt Wonka ${ }^{1}$, Iskander De Bruycker ${ }^{2}$, Dirk De Bièvre ${ }^{2}$, Caelesta Braun ${ }^{3}$ and Jan Beyers ${ }^{2, *}$ \\ ${ }^{1}$ Bremen International Graduate School of Social Sciences, University of Bremen, 28334 Bremen, Germany; \\ E-Mail: awonka@bigsss.uni-bremen.de \\ 2 Department of Political Science, University of Antwerp, 2000 Antwerpen, Belgium; E-Mails: \\ iskander.debruycker@uantwerpen.be (I.B.), dirk.debievre@uaantwerpen.be (D.B.), Jan.Beyers@uantwerpen.be (J.B.) \\ ${ }^{3}$ Institute of Public Administration, University of Leiden, 2511DP Den Haag, The Netherlands; \\ E-Mail: c.h.j.m.braun@fgga.leidenuniv.nl \\ * Corresponding author
}

Submitted: 17 November 2017 | Accepted: 27 April 2018 | Published: 26 September 2018

\begin{abstract}
Contemporary studies on interest group politics have mainly used single interest organizations as their central objects of study. This has led to a rich body of knowledge on the motivations of interest group mobilization, strategy development and even policy access and influence. The focus on single interest groups, however, has resulted in limited knowledge on aggregate patterns of interest groups' activity. This article seeks to address this lacuna, by examining patterns of mobilization and conflict of interest groups' activity in EU legislative policymaking. To do so, it adopts a unique policy-centred research design and an empirical assessment of policy mobilization for a sample of 125 EU legislative proposals based on extensive media coding as well as structured elite interviews. We find that levels of policy mobilization vary substantively across different legislative proposals and that political conflict between interest groups is remarkably low. This suggests that interest group conflict and mobilization contribute little to EU politicization and that in cases where interest groups voice opposing positions, conflicts do not occur between business and non-business groups. Our findings have important implications for our understanding of interest groups in EU legislative policymaking.
\end{abstract}

\section{Keywords}

European Union; interest groups; legislative policy-making; mobilization; political conflict

\section{Issue}

This article is part of the issue "Multidisciplinary Studies" in Politics and Governance.

(C) 2018 by the authors; licensee Cogitatio (Lisbon, Portugal). This article is licensed under a Creative Commons Attribution 4.0 International License (CC BY).

\section{Introduction}

Contemporary studies on interest group politics mostly take single interest organizations as their analytical point of departure. This has led to rich insights into the motivations of mobilization, strategy development, and even policy influence. The focus on single interest groups, however, has resulted in limited knowledge on aggregate patterns of interest group mobilization and conflict. This article seeks to address this lacuna, by identifying patterns of mobilization and conflict of inter- est groups' activity in EU legislative policymaking. Interest groups' mobilization is often thought to significantly contribute to policymaking dynamics in the European Union (EU). While many interest groups populate Brussels (Berkhout \& Lowery, 2008), this does not mean that interest groups' political activities contribute to political polarization in the EU (but see Dür, Bernhagen, \& Marshall, 2015; Klüver, 2011; Koopmans, 2007; Mahoney, $2004,2008)$. With this study, we seek to clarify the role of interest groups in the EU by systematically exploring both the extent to which they mobilize on specific leg- 
islative policy proposals as well as the conflicts resulting from varying levels of mobilization. From an elitist perspective, we could expect interest mobilization to be dominated by corporate and affluent lobby groups (OIson, 1965; Schattschneider, 1960). Based on more recent accounts, which characterize EU interest mobilization as "chameleon pluralism", in contrast, we rather expect that the prevalence of either specific or diffuse groups is likely to vary according to the issues and policy areas in question (Coen \& Katsaitis, 2013).

We add to these theoretical perspectives by exploring the conflicts that divide mobilized interest populations. Implicitly, elitists have assumed that interest group conflict is characterized by structural divides between specific or upper-class segments of society on the one hand and diffuse or disadvantaged segments of society on the other hand (Olson, 1965; Schattschneider, 1960). This assumption gave rise to a rich body of empirical studies exploring the extent and nature of bias in favour of specific business groups over civil society or diffuse interests (see for instance Dür et al., 2015). We assess the scope and external validity of this implicit assumption by exploring the nature of interest group conflict in the EU on a random sample of policy proposals. In addition, we address an implicit assumption in interest group studies, something we could call the "pluralist fallacy", which leads us and others often to assume that where there are policies, there will be interest group mobilization and contestation. Yet, the few systematic country studies that exist (Baumgartner \& Leech, 2001; Burstein, 2014; Halpin, 2011) and our study on the EU find that in a majority of policy-making processes there is little or no interest group lobbying. Both varying levels of interest group mobilization and the resulting conflicts have been shown to have a systematic impact on the politics and the outcomes of policymaking processes across different political systems (Baumgartner, Berry, Hojnacki, Leech, \& Kimball, 2009; Berkhout et al., 2015; Burstein, 2014; Halpin, 2011; LaPira, Thomas, \& Baumgartner, 2014). To the best of our knowledge, our study is the first to investigate variance in levels of policy mobilization by interest groups for a sample of EU legislative proposals, as well as being the first to study the resultant patterns of conflict.

Our analysis of interest groups' policy mobilization and the resultant conflict patterns takes actual legislative policymaking processes as a point of departure. We do so to avoid biased inferences on groups' relevance in EU policymaking which may result from a focus on a few "important" cases, i.e. policies that were strongly contested by numerous political actors (e.g., Dür \& Mateo, 2014; Lindgren $\&$ Persson, 2008). To this end, we study policy mobilization by interest groups on $125 \mathrm{EU}$ legislative proposals that were initiated by the European Commission (EC) between 2008 and 2010. We adopt the established definition of interest groups as private, i.e., non-state, organizations which do not hold public office and that advocate, amongst other things, different societal, economic and political ideas and interests. Although they are certainly not the only instruments for EU policymaking, legislative acts embody important EU policies as they apply generally and are binding. Moreover, from a research design perspective, legislative policies are a good choice as they allow one to study lobbying on policies that are equivalent in legal and institutional terms.

Our analysis shows, in line with the legislative politics literature (Hix \& Hoyland, 2013; Mattila, 2009), that only a small amount of legislative lobbying is characterized by high levels of policy mobilization while for most instances we observe low levels of policy mobilization. Moreover, and in contrast to a popular view, instances where business and non-business groups explicitly oppose each other-which we call structural conflict-are quite uncommon. Our analysis thus shows a much less dominant fault line of business pitted against NGOs than is commonly assumed and reflected in the business vs nonbusiness distinction that is prevalent in much interest group research. Indirectly, our observations lend support to the proposition that the politicization of EU politics does not primarily stem from conflicts among interest groups, but rather from party politics, territorial (member state driven) conflict, or inter-institutional conflict.

The article is structured as follows. In the next section, we introduce and define the three main concepts upon which we rely to structure our analysis: policy mobilization, policy polarization, and between-group divisiveness. We subsequently describe the policy-centred research design that we applied. The fourth section presents the results on the scope of policy mobilization and the nature of conflicts in EU legislative lobbying. We conclude the article with a brief summary of our results and a discussion on future research.

\section{Policy Mobilization by Interest Groups and Political Conflict in EU Legislative Policymaking}

We argue that studying both policy mobilization and interest group conflict as two distinct yet related phenomena adds to our knowledge on to the role of interest groups in EU legislative policymaking. To date, most quantitative studies have examined varying levels of interest group access to the EU's institutional venues and have excluded policy polarization. (Bouwen, 2004; Dür \& Mateo, 2012; Eising, 2004, 2007; for exceptions see: Dür et al., 2015; Klüver, 2011). In their studies of lobbying in the United States, however, Baumgartner et al., show that only a few policy proposals led to considerable policy polarization with interest groups taking very different positions on the respective proposal (2009, p. 61). This shows that there are good reasons to suggest that the number of groups and type of conflict are associated and that studying both mobilization rates as well as the level and degree of political conflict associated with concrete policy proposals adds to our understanding of position-taking in EU legislative policymaking. By investigating these aspects of EU interest group politics, we add to the literature on the nature of (EU) inter- 
est group politics (Coen \& Katsaitis, 2013; Olson, 1965; Schattschneider, 1960). Moreover, we add to the literature on the (non-) politicization of the EU (De Wilde, Leuphold, \& Schmidtke, 2016) and the contribution which interest groups add to the (non-) politicization of EU policy-making processes, an aspect which has so far not received any systematic attention in this debate. We use policy mobilization as the first central concept to structure our analysis of interest group advocacy and conflict in EU policymaking. In contrast to existing studies, we thus focus on mobilization per policy proposal in legislative EU politics, rather than on group mobilization in general, following common findings in the literature that the issue-context matters for interest mobilization (Klüver, Braun, \& Beyers, 2015). We capture interest group mobilization along a scale ranging from zero, i.e., no mobilization, to the maximum number we observe in our policy sample.

Our other two central concepts focus on conflict between groups. We distinguish two types of conflict: First, the level of policy polarization among interest groups, and, second, the level and type of between-group divisiveness, i.e., the number of conflicting positions voiced by different types of groups. Policy polarization refers to the positions that groups take vis-à-vis the legislative proposal submitted by the EC to the Council and the European Parliament (EP). These positions can range from a group's full support of a proposal to fundamental opposition to it. Policy polarization captures the extent to which positions voiced by interest groups vary on specific issues of a policy proposal and not the degree of support or opposition vis-à-vis the EC's policy proposal. If all groups take the same supportive position, there is no polarization of interest groups' positions vis-à-vis the EC's proposal. In a case of non-polarization, groups could, for example, unequivocally agree in their opposition to or support for a policy proposal. Policy polarization accordingly increases with an increasing variety of interest groups' positions on a policy proposal and thus captures the (level of) conflict amongst themselves which interest groups introduce into EU policymaking. A possible explanation for limited policy polarization could be reputational concerns of interest groups. They want to come across as trustworthy and knowledgeable interlocutors, allowing them to enter stable, non-conflictual and reciprocally beneficial relationships with policymakers (Browne, 1990; Gray \& Lowery, 1996; Heaney, 2004; Lowery, 2007, p. 51). In order not to damage their trustworthy reputation, interest groups are tempted to adopt a supportive attitude and refrain from expressing strong opposition to policy proposals. Therefore, we expect policy polarization among interest groups as well as opposition to the EC's policy proposals generally to be relatively low. At the same time, levels of policy mobilization are likely to correlate positively with policy polarization: If policy proposals attract the attention of many interest groups, they may show less restraint in voicing opposition. For proposals with high levels of interest group mo- bilization, groups may have incentives to demonstrate to their members and potential members that they are actively trying to secure their interests. Consequently, the level of policy polarization should be greater for proposals with high levels of interest group mobilization than those with low levels.

Our third analytical focus lies on between-group divisiveness. Between-group divisiveness addresses the relationship between the type of interest represented and the positions groups take when mobilizing. While policy polarization is about the conflict among interest groups and policymakers, between-group divisiveness is about the extent to which groups' positions vary between different types of groups. We distinguish two types of interests: business and non-business groups. Some recent scholarship on interest groups suggests structural between-group divisions in which business groups are consistently pitted against groups representing broader citizen interests (Bernhagen, 2012; Dür et al., 2015, p. 952). Moreover, there are a number of studies that show that business groups and citizens groups are unequally endowed with resources and that the former's greater ability to keep generating greater resources over a prolonged period of time provides them with more policy influence (Gilens \& Page, 2014; but see Baumgartner et al., 2009; Klüver, 2011) and better access (Dür \& Mateo, 2013, 2014; Eising, 2007).

In order to assess the nature of conflict between business and non-business interests, we conceptualize between-group divisiveness in two ways: structural conflict and cross-type conflict. First, we denote divisions between business and non-business interest groups as structural conflict, when business groups voice positions on all contested issues of a policy proposal that are invariably in opposition to the positions voiced by nonbusiness groups. Second, divisions between groups can also run right across business and non-business interests. We denote mobilization patterns in which business and non-business interests take the same positions and oppose other business or non-business interests as cross-type conflict. We empirically investigate the extent to which between-group divisiveness matches the patterns characterizing structural conflict or rather those that characterize cross-type conflict. Should our exploration show that cross-type conflicts are a regular occurrence in policy mobilization in the EU and that structural conflicts are rare, we will take this finding as an indication that mobilization in the EU is driven by interest groups' policy-specific rather than by their structural interests.

\section{Data and Research Design}

To analyse aggregate patterns of interest group mobilization and conflict, we adopt a policy-centred research design. Such a design not only allows us to examine policy mobilization across different policy domains or institutional venues, but also to relate interest group activity to specific characteristics of concrete policy initiatives, 
such as the number of issues, i.e., contested aspects of a policy proposal, or the variation of interest groups' positions. This policy-centred design uniquely allows us to examine the relationship between interest groups' policy mobilization and political conflict at the level of specific legislative cases (see Baumgartner et al., 2009, for a similar design). We use data from the INTEREURO project, which analyses lobbying and interest group influence for a sample 125 European legislative proposals (directives and regulations) which the EC submitted between 2008 and 2010. As political attention is generally characterized by highly non-linear distributions with a small number of highly contested cases, we did not opt for an unweighted randomized sampling procedure. Instead, our sampling strategy aimed at striking a balance between having enough cases with at least some political mobilization as well as sufficient cases where no or little lobbying takes place. To select politically contested EU legislative proposals, we relied on their coverage in five news sources: Agence Europe, European Voice, the Financial Times, the Frankfurter Allgemeine Zeitung, and Le Monde (Beyers, Dür, Marshall, \& Wonka, 2014b).

We randomly selected 48 proposals for directives and 41 proposals for regulations that were mentioned in at least two media sources. This low threshold ensures substantial variation in public salience across proposals in the sample. To introduce sufficient variation, we also included a randomly selected set of nine proposals for directives and nine proposals for regulations that did not meet the media coverage criterion. Finally, we added 18 legislative proposals for which the EC held public consultations and where consultation documents were available. We did this for pragmatic reasons as we wanted to benefit from the additional data that is available for consultation cases. Although we sampled 125 legislative proposals, our analyses are based on a set of 116 distinct legislative cases because 16 proposals were-in different ways-highly interconnected and should be seen as part of one legislative initiative consisting of two to four leg- islative proposals. Since we applied a threshold to ensure variance regarding levels of mobilization and conflict in our random sample of proposals, we think our sample is highly appropriate to arrive at externally valid findings. The sample comprises a substantive share of proposals going beyond a few highly salient and conflictual cases that are foremost in the minds of citizens and scholars and which should (because of its random nature) reflect the universe of proposals on which mobilization and conflict can be observed (Beyers et al., 2014b).

The mapping of policy mobilization started with the archiving of news articles reporting on organized interests that were politically active on a particular legislative proposal (see Table 1; STEP I). In addition, we conducted two sets of interviews. First, 95 experts in the EC were interviewed (STEP II). During these interviews 125 policy issues as well as 460 interest groups that were lobbying on a proposal, but were not mentioned in media sources, were identified. Next (STEP III), these interviews with EC experts were followed by 143 interviews with EU-level interest group representatives involved in lobbying on these legislative proposals (Beyers, Braun, Marshall, \& De Bruycker, 2014a). The largest part (64\%) of our interest group respondents represent business associations, another $28 \%$ represent NGOs, and the remaining 8 percent are officials from professional organizations, firms, or labour unions.

The interviews with EC-experts covered 67 policy proposals while the interviews with interest group officials focused on 72 policy proposals. One of the most important reasons why we did not interview EC-experts or interest groups' representatives on all 116 cases is that our pre-research showed that in 38 cases almost no lobbying took place (see below). We dropped another six cases because we could not convince interest groups to share their views on them. In total, we identified 1,027 individual interest groups that were active in the sampled cases. As quite a number of groups were involved in policymaking on several policy proposals, they appear mul-

Table 1. Mapping mobilized interests for 116 legislative proposals.

\begin{tabular}{lll}
\hline & $\begin{array}{l}\text { Number of interest groups identified } \\
\text { in relation to cases }\end{array}$ & Number of policy issues identified \\
\hline STEP I: media analysis & $\begin{array}{l}625 \text { actor involvements } \\
967 \text { statements in } 474 \text { articles }\end{array}$ & \\
\hline STEP II: 95 expert interviews (EC) & 460 actor involvements & 125 issues \\
\hline STEP III: 143 interviews & 273 additional actor involvements & 176 issues on top of what we \\
with interest group officials & (not identified in STEP I AND II) & identified in STEP I \\
\hline Additional actors and issues identified & 186 & 38 issues not identified in earlier steps \\
through other sources (websites, other & (not identified in STEP I, II and III) & \\
media sources, short telephone & & \\
interviews, interviews with MEPs) & & 339 issues \\
\hline $\begin{array}{l}\text { Total number of groups and } \\
\text { issues identified }\end{array}$ & 1,544 dyads & \\
\hline
\end{tabular}


tiple times in the dataset. This leads to an overall number of 1,544 instances of interest groups that were identified-through our media analyses and the personal interviews - in connection with the sampled policy cases.

In our interviews with the EC and organized interests, we identified 298 important issues in these proposals, and an additional 38 in those with officials from the EP (Baroni, 2014). For each proposal, we tried to identify key lines of conflict as well as the policy position of the mobilized interest group. On 47 issues, we were not able to interview interest groups because none were active on the issue, or because we could not find an interest group willing to cooperate, or because the interviewee did not have sufficient recollection of the issue. Hence, 292 of the 339 issues were covered by interviews with at least one interest group. As groups did not always articulate a clear position, because respondents refused to answer or did not remember details, we lack position information on 20 issues. Detailed evidence on $\mathrm{N}=272$ issues allows us to assess the policy contestation (groups' positions vis-à-vis the EC's policy proposal), policy polarization (the variation between position on a policy proposal) and between-group divisiveness (the extent to which position vary between different types of groups). We measured contestation and polarization by asking respondents to assess whether the lobbying activities for each issue aimed: 1) at "seeking major changes" or at "blocking the proposal", 2) "supporting the proposal, but asking for changes", or 3) "supporting the EC proposal as it stands". All media statements were coded in the same way. We can, therefore, assess the level of conflict at the level of legislative proposals as well as at the level of specific issues, i.e., specific aspects of a specific legislative proposal.

\section{Empirical Analysis: Policy Mobilization and Patterns of Conflict}

We start by analysing policy mobilization. Figure 1 ranks the sampled proposals with those generating most lobbying attention to the left. As expected, policy mobilization varies considerably across policy proposals. Only a relatively small number attract the attention of many groups, while for most proposals we observe the mobilization of only a dozen or fewer interest groups. In 6 cases, no single interest group provides useful information and in 38 cases, short telephone interviews (with ECexperts and interests groups), media sources and other documents demonstrate no interest group mobilization. At the same time, of the total set of 116 policy proposals, 72 are characterized by at least some policy mobilization. Moreover, within this set policy mobilization is heavily skewed. In fact, the mobilization efforts of about 50 percent of all groups $(N=1,544)$ that we identified concern only 20 percent of the 116 policy proposals. In addition, business interests are considerably more active in EU policymaking than non-business groups. As Figure 2 shows, in the large majority of policy proposals in our sample, the share of business groups that mobilized is considerably higher than that of non-business groups. The fact that increasing levels of mobilization are characterized by a dominance of business groups contradicts the argu-

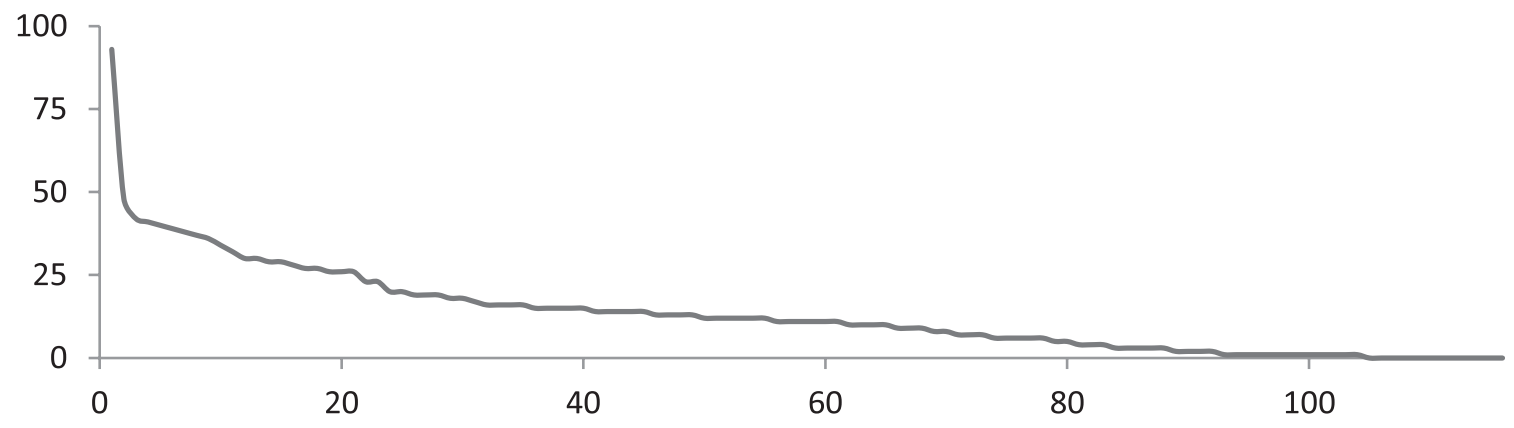

Figure 1. Number of identified interest groups $(n=1,544)$.

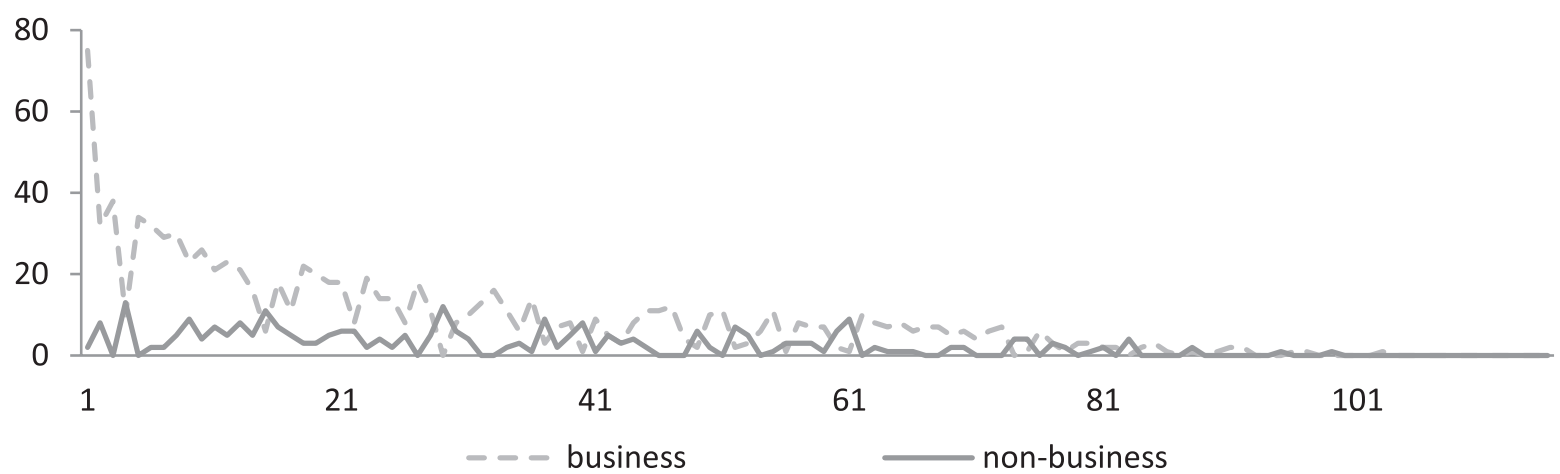

Figure 2. Mobilization of business and non-business groups $(n=1,544)$. 
ment that citizen and other diffuse interest groups profit from an expansion of conflict (Schattschneider, 1960). Public interest groups' reliance on outside lobbying and an expansion of conflict to compensate structural disadvantages (Dür \& Matteo, 2013) might thus be of limited political effectiveness. Interestingly, this is particularly true for those policy proposals which led to high levels of policy mobilization. Thus, while interest groups are actively engaging in EU policymaking, their relevance in EU policymaking differs greatly across policy proposals. The vast majority of legislative policymaking processes gain little or no attention from organized interests.

The Figures 1, 2 and 3 show the scope of political mobilization on $116 \mathrm{EU}$ legislative proposals.

A (Spearman rho) correlation of 0.78 confirms the positive relationship between the number of contested issues (Figure 3) and the level of policy mobilization (Figure 1). Contested policy issues are specific aspects of a legislative proposal where organized interests took a conflicting position and disagreed on the preferred policy outcome. A typical example of such an issue is the testing of non-human primates in research as part of an EC proposal on animal protection [COM (2008) 543], where policy positions varied from outright opposition and total abolition of testing to continuation of the status quo based on best practices. The fact that encompassing mobilization (towards the left side of Figure 1 ) is positively related to the number of contested issues indicates that a policy's regulatory scope influences interest group attention. Policy proposals with a broader scope attract the attention of a larger and more diverse set of interest groups that raise diverse demands and target a larger number of policy issues. On the other hand, in policymaking processes characterized by low levels of mobilization (right side in Figure 1) interest groups deal with a rather specific and limited number of issues.

Having investigated levels of policy mobilization, we now turn to our analysis of political conflict and the relationship between policy mobilization and political conflict. In the section above we differentiated between two types of conflicts: policy polarization (Table 2), i.e., the positions taken by interest groups on policy proposals and between-group divisiveness (Figure 2), i.e., the types of groups opposing each other. While the unit of analysis remains policy proposals, we draw on issue-level in- formation for groups' positions and our assessment of political conflict caused by interest groups (for the 72 proposals for which we have data).

We start by analysing policy polarization, which we measure with the ordinal dispersion index (ranging from 0 to 1 ) of the different positions adopted by interest organizations with respect to the contested issues. For one third ( $N=39$, Table 2, leftmost column) of the policy proposals, we observe no controversy among interest groups. In addition, we observed limited opposition of interest groups to 25 policy proposals: interest groups only asked for major changes or tried to block the whole proposal in 10 out of 72 issues of these 25 policy proposals, while they voiced full support for 31 issues (37 percent; see Table 2). The average level of policy polarization for these policy proposals, i.e., the average variation of interest groups' issue positions in these proposals, is 0.2 (Table 2 , rightmost column). The proposals on which we observed limited controversy and a low level of policy polarization are also characterized by relatively low levels of mobilization (8.7 groups; Table 2, column 3). One typical example of a policy for which we observe limited polarization is the 2009 EC proposal laying down minimum standards for the reception of asylum seekers [COM(2008)815]). While some member states pledged for there to be a low level of harmonization of minimum standards for the reception of asylum seekers, the European Council on Refugees and Exiles (ECRE) and Amnesty International supported the EC in favour of a full harmonization. Indeed, there was some controversy, particularly among the member-states and the EC although lobbyists and the EC were largely on the same page for this particular legislative case of asylum policy. In addition, for 21 percent of the proposals, we find moderate levels of policy polarization (0.4; Table 2 ). The number of issues that were contested by interest groups in policymaking on these proposals was considerably higher than in cases with limited polarization (147 versus 72 ) as was the share of issues on which interest groups asked for major changes ( 25 percent) as well as the average number of groups that mobilized on these proposals (15.7; Table 2).

Finally, 20 percent of the policy proposals attracted relatively high attention from interest groups (35 interest groups) which were contesting in total 186 issues, i.e., about 45 percent of all contested issues. These pol-

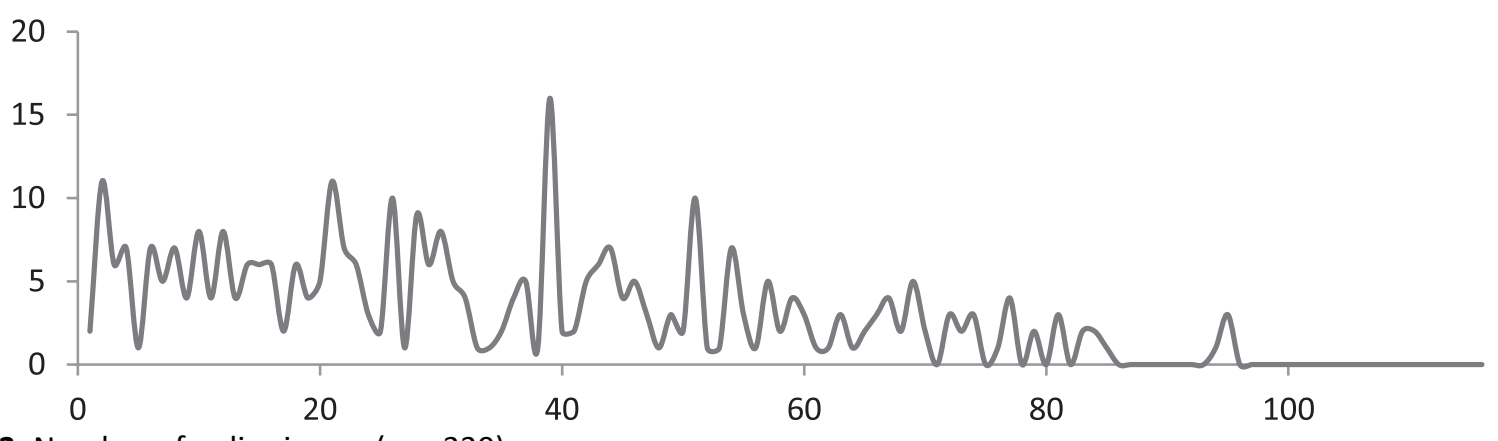

Figure 3. Number of policy issues $(n=339)$. 
Table 2. Policy polarization by interest groups in EU policy-making.

\begin{tabular}{|c|c|c|c|c|c|c|c|}
\hline & & Mobilization & Issue scope & & Position & & $\begin{array}{c}\text { Policy } \\
\text { polarization }\end{array}$ \\
\hline & $\begin{array}{l}\text { Share of } \\
\text { proposals } \\
\text { from } \\
\text { overall } \\
\text { sample }\end{array}$ & $\begin{array}{c}\text { N mobilized } \\
\text { groups } \\
\text { (average } \\
\text { number per } \\
\text { proposal, } \\
\text { min-max) }\end{array}$ & $\begin{array}{l}\mathrm{N} \text { issues } \\
\text { on which } \\
\text { groups took } \\
\text { a position } \\
\text { (N issues } / \%)\end{array}$ & $\begin{array}{l}\mathrm{N} \text { groups that } \\
\text { demand major } \\
\text { changes or } \\
\text { blocking the } \\
\text { proposal } \\
\text { (N groups, \%) }\end{array}$ & $\begin{array}{l}\text { N groups } \\
\text { supporting } \\
\text { proposal, but } \\
\text { demanding } \\
\text { changes } \\
\text { (N groups, \%) }\end{array}$ & $\begin{array}{l}\text { N groups } \\
\text { supporting } \\
\text { the proposal } \\
\text { as proposed } \\
\text { (N groups, \%) }\end{array}$ & $\begin{array}{l}\text { Level of } \\
\text { group } \\
\text { conflict } \\
\text { (average } \\
\text { dispersion, } \\
0-1 \text { ) }\end{array}$ \\
\hline $\begin{array}{l}\mathrm{N}=5 \text { policies } \\
\text { no information }\end{array}$ & $5 \%$ & & - & - & - & - & - \\
\hline $\begin{array}{l}\mathrm{N}=39 \text { policies } \\
\text { no polarization }\end{array}$ & $33 \%$ & & - & - & - & - & - \\
\hline $\begin{array}{l}\mathrm{N}=25 \text { policies } \\
\mathrm{N}=72 \text { positions } \\
\text { limited } \\
\text { polarization }\end{array}$ & $22 \%$ & $\begin{array}{c}8.72 \\
(3-12)\end{array}$ & $63(23 \%)$ & $10(14 \%)$ & 31 (43\%) & 31 (43\%) & 0.2 \\
\hline $\begin{array}{l}\mathrm{N}=24 \text { policies } \\
\mathrm{N}=147 \text { positions } \\
\text { moderate } \\
\text { polarization }\end{array}$ & $21 \%$ & $\begin{array}{c}15.67 \\
(13-20)\end{array}$ & 99 (36\%) & $40(27 \%)$ & 61 (41\%) & $46(31 \%)$ & 0.4 \\
\hline $\begin{array}{l}\mathrm{N}=23 \text { policies } \\
\mathrm{N}=186 \text { positions } \\
\text { considerable } \\
\text { polarization }\end{array}$ & $20 \%$ & $\begin{array}{c}34.96 \\
(23-93)\end{array}$ & 110 (40\%) & $71(38 \%)$ & 67 (36\%) & $48(26 \%)$ & 0.6 \\
\hline Total $(\mathrm{N})=116$ & 100 & & 272 & 121 & 159 & 125 & \\
\hline
\end{tabular}

icy proposals are characterized by considerable policy polarization (0.6) which results from many groups taking opposing positions on the issues of these proposals (Table 2). One example of a policy that led to strong policy contestation of interest groups vis-à-vis EC proposals and to considerable conflicts between interest groups is the legislative proposal on combating the sexual abuse of children and child pornography [COM (2010) 94]. A controversial issue in that policy concerned the question of whether or not to block child pornography on the internet. More concretely, a coalition of children right groups advocated the compulsory blocking of these websites, while some internet rights groups argued for the prohibition of blocking and "Internet freedom".

Our analyses of policy polarization show a significant relationship between the levels of mobilization and policy polarization: when a relatively large number of groups mobilize on a policy proposal, they address a relatively high number of policy issues which results in a relatively strong polarization of the positions taken by interest groups on policy proposals (Table 2). As previously discussed, interest groups have an incentive to limit controversy with policymakers because of their mutually dependent relationship. The fact that we observe no or only moderate polarization for 55 percent of the policy proposals $(33+22$; second row in Table 2$)$ and substantial support even in mobilization processes that lead to high levels of policy polarization ( 31 percent and 26 percent, Table 2, columns 5 and 6) is in line with this argument (Heaney, 2004; Lowery, 2007).

In Figure 2 we show that for a large share of policy cases both business and non-business interest groups mobilize, but that in most instances business groups outnumber the mobilized non-business interests. Yet, the question is to what extent the mobilization pattern in EU lobbying reflects structural cleavages. Therefore, we turn to the analysis of between-group divisiveness and the question of who is opposing whom. The analytical focus is on what we conceptualized as structural conflicts and crosstype conflicts. While our unit of analysis is legislative proposals, we draw on issue level data to identify interest groups' (issue) positions in specific policy debates. Moreover, while our analytical focus is on structural conflicts and cross-type conflicts, we also identify those policy proposals in which neither structural nor cross-type conflicts occurred. The prevalence of cross-type conflicts may well be an indication that policies and their potential effects rather than the type of interest represented by a group (i.e., business or non-business) drive conflict between interest groups during their policy mobilization efforts.

Figure 4 shows that structural conflicts are actually quite rare during interest groups' mobilization on EU policy proposals. In one-third of policy proposals, only business mobilized $(\mathrm{N}=36)$ and, in far fewer cases 


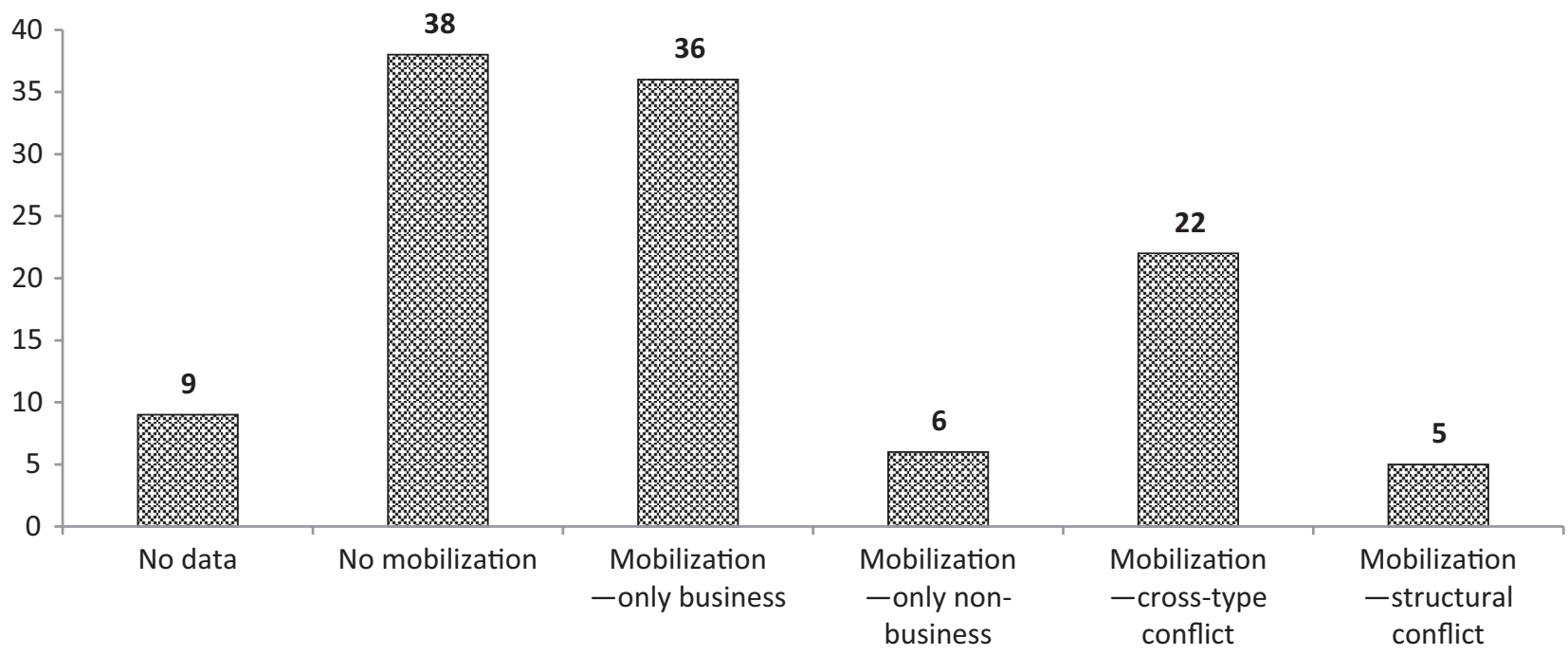

Figure 4. Between-group divisiveness in interest groups' EU policy mobilization $(\mathrm{N}=116)$.

Note: Positions at issue-level. Proposals classified as marked by "cross-type conflict" if business and non-business groups voiced similar positions (support, some change, major change/blocking) on at least one of the issues of the legislative case. Proposals in which business and non-business groups never voiced similar positions on any of the issue that constitute the proposal were marked as "structural conflict".

$(N=6)$, only non-business groups voiced a clear position. A substantial number of these policy proposals were only weakly conflictual. In addition, we observe structural conflicts only in policymaking processes in five of the 116 policy proposals. At the same time, cross-type conflicts are a more common feature in interest groups' mobilization on EU policy proposals $(\mathrm{N}=22)$. These findings are theoretically relevant in at least two regards: first, the fact that in most policymaking processes we find mobilization of one specific type of interest and the fact that these policymaking processes are marked by limited contestation highlights the prevalence of the rather non-conflictual character of interest group politics in EU policy-making. Second, that cross-type conflict is more prevalent than structural conflict indicates that policy mobilization by interest groups and groups' positions are considerably driven by the substance of policies and their potential effects on diverse constituencies. This observation speaks against a primordial understanding of policy mobilization by EU interest groups as a process that pits business against non-business interests. Instead, the evidence suggests that mobilized interest group communities can be quite heterogeneous and diverse.

\section{Conclusion}

This article presented the first study to map aggregate patterns of interest group mobilization and conflict in EU legislative policymaking. Our policy-centred research design and the systematic mapping of policy mobilization for a substantial sample of policy proposals shows that policy mobilization by interest groups in the EU is strongly skewed: high levels of mobilization are restricted to a relatively small number of policy proposals, while most policy proposals are characterized by low lev- els of policy mobilization (for similar findings see Baumgartner \& Leech, 2001; Burstein, 2014; Halpin, 2011). We also find low levels of policy mobilization to be related to limited policy polarization and low levels of betweengroup divisions. Policymaking processes with high levels of policy mobilization are at the same time characterized by high levels of policy polarization (Table 2). Finally, regarding the nature of between-group divisions, we found structural conflicts between business and non-business interests to be rare. Cross-type conflicts, in which business and non-business groups take the same positions and oppose another heterogeneous community of business and non-business groups taking similar positions are more prevalent.

Our analyses contribute to the EU interest group literature and the scholarship on EU legislative policymaking. First, our finding that cross-type conflicts are more prevalent in EU policymaking (compared to structural conflicts), suggests the need for further research into the factors explaining groups' position-taking in EU policymaking (Halpin \& Jordan, 2009). While the analytical distinction between different types of groups (e.g., business or specific versus citizens or public interest groups) may be important to account for varying levels of activities and resources (Dür \& Mateo, 2012, 2013), it seems less effective to account for the specific policy positions adopted by interest groups and the political conflicts resulting from them. In addition, our finding that policy mobilization is driven by cross-type rather than structural conflict merits further research into the relationship between levels of mobilization and the nature of betweengroup divisiveness.

Overall, we observed that groups contribute little to the politicization of EU public policy. To obtain a more comprehensive understanding of the level of con- 
flict in EU policymaking, future research could broaden our perspective by investigating how policy mobilization by interest groups relates to conflicts in other legislative arenas, the Council of Ministers and the EP, as well as between political parties more generally (Helbling, Hoeglinger, \& Wüest, 2010; Hutter \& Grande, 2014). EU legislative policymaking is, in general, rather consensual which, as we observe, seems to spill-over to the EU interest groups' arena (Mattila, 2009, p. 844; Thomson, Boerefijn, \& Stokman, 2004). In other words, in EU legislative policymaking interest groups operate in an environment in which policymakers show a rather limited inclination to engage in open political conflicts. This might also discourage interest groups from open contestation and might be reflected in the patterns of mobilization which we have reported. Future studies could further unravel this observation by identifying the conditions that facilitate or contain the nature and scope of conflicts in EU policymaking.

Although some EU policymaking processes are increasingly politicized (De Wilde et al., 2016), at present, there is no reason to believe that our findings (from 2008-2010) on interest group mobilization and interest groups' (limited) contribution to the contestation of EU policy-making are not relevant. Even though recent cases such as TTIP, glyphosate, and Brexit have illustrated the politicizing potential of EU politics, still this politicization will be limited to a few cases which feature on the newspaper headlines and are forefront in the minds of citizens and scholars (De Bruycker, 2017). The lion's share of policy conflicts still unfold under the radar of public scrutiny and are characterized by an absence or low level of conflicts. Future studies could further explore the theoretical implications of our findings. Moreover, future studies should investigate how the salience which interest groups attribute to EU policies relates to the salience assessments of other actors and to the overall salience of EU (legislative) policy-making (Beyers, Dür, \& Wonka, 2017).

In line with elitist expectations (Olson, 1965; Schattschneider, 1960), we observed that mobilized interest group communities were dominated by business lobby groups. However, the degree of business prevalence depends on the issues or policy area at stake (see also Coen \& Katsaitis, 2013) and conflicts between diffuse and specific interest communities are the exception rather than the rule. We find that, quite regularly, business and non-business interests take similar positions (see also Beyers \& De Bruycker, 2017). The mobilization bias of business organizations over civil society groups might, therefore, be less problematic, or at least less ubiquitous than sometimes argued. Future research could further explore the biases that emerge within mobilized business or civil society communities respectively. Since intra-sectoral conflicts are commonplace in EU policymaking, it would be relevant to further explore the nature of these conflicts and whether some business groups systematically prevail over others.
Finally, of course, it would be very interesting to compare our findings on interest groups' policy mobilization in the EU with studies on groups' policy mobilization in other political systems. This would allow us to assess if and to which extent our findings reflect particularities of the EU's political system or if, as the few existing studies indicate (Baumgartner \& Leech, 2001; Burstein, 2014; Halpin, 2011), the patterns we found reflect more general patterns. Comparative or comparatively oriented studies would also allow us to investigate if and how institutional, policy- and party-system related factors contribute to interest groups' policy mobilization and the policy polarization resulting thereof. We hope to be in the position to make such comparisons in the future, even if designing these studies and collecting the data will be very demanding.

\section{Acknowledgements}

We would like to thank the reviewers of the article for their valuable and constructive feedback. In addition, we would like to thank the panel discussant and attendants at the ECPR Standing Group on European Integration conference in The Hague (2014), as well as colleagues in our departments, for comments which helped us improve the article. We acknowledge financial support from the Research Foundation-Flanders (FWO-V, grant GA $171-11 \mathrm{~N})$, the European Science Foundation (ESF, grant 10-ECRP-008), the Faculty of Social Sciences of the University of Antwerp and the Staats- und Universitätsbibliothek Bremen.

\section{Conflict of Interests}

The authors declare no conflict of interests.

\section{References}

Baroni, L. (2014). Information counts: Interest group success in the European Parliament. (Doctoral dissertation). University of Salzburg, Salzburg, Austria.

Baumgartner, F., \& Leech, B. (2001). Interest niches and policy bandwagons: Patterns of interest group involvement in national politics. The Journal of Politics, 63(4), 1191-1213.

Baumgartner, F., Berry, J., Hojnacki, M., Leech, B., \& Kimball, D. (2009). Lobbying and policy change: Who wins, who loses, and why. Chicago, IL: University of Chicago Press.

Berkhout, J., Carroll, B., Braun, C., Chalmers, A., Destrooper, T., Lowery, D., \& Rasmussen, A. (2015). Interest organizations across economic sectors: explaining interest group density in the European Union. Journal of European Public Policy, 22(4), 462-480.

Berkhout, J., \& Lowery, D. (2008). Counting organized interests in the European Union: A comparison of data sources. Journal of European Public Policy, 15(4), 489-513. 
Bernhagen, P. (2012). Who gets what in British politics-And how? An analysis of media reports on lobbying around government policies, 2001?7. Political Studies, 60(3), 557-577.

Beyers, J., Braun, C., Marshall, D., \& De Bruycker, I. (2014a). Let's talk! On the practice and method of interviewing policy experts. Interest groups \& Advocacy, 3(2), 174-187.

Beyers, J., \& De Bruycker, I. (2017). Lobbying makes (strange) bedfellows: Explaining the formation and composition of lobbying coalitions in EU legislative politics. Political Studies, 1-26. DOI: 10.1177/ 0032321717728408

Beyers, J., Dür, A., Marshall, D., \& Wonka, A. (2014b). Policy-centred sampling in interest group research: Lessons from the INTEREURO project. Interest groups \& Advocacy, 3(2), 160-173.

Beyers, J., Dür, A., \& Wonka, A. (2017). The political salience of EU policies. Journal of European Public Policy, 1-12. DOI: 10.1080/13501763.2017.1337213

Bouwen, P. (2004). Exchanging access goods for access: A comparative study of business lobbying in the European Union institutions. European Journal of Political Research, 43, 337-369.

Browne, W. (1990). Organized interests and their issue niches: A search for pluralism in a policy domain. The Journal of Politics, 52(2), 477-509.

Burstein, P. (2014). American public opinion, advocacy, and policy in Congress: What the public wants and what it gets. Cambridge: Cambridge University Press.

Coen, D., \& Katsaitis, A. (2013). Chameleon pluralism in the EU: An empirical study of the European Commission interest group density and diversity across policy domains. Journal of European Public Policy, 20(8), 1104-1119.

De Bruycker, I. (2017). Politicization and the public interest: When do the elites in Brussels address public interests in EU policy debates? European Union Politics, 18(4), 603-619.

De Wilde, P., Leuphold, A., \& Schmidtke, H. (2016). Introduction: The differentiated politicisation of European governance. West European Politics, 39(1), 3-22.

Dür, A., Bernhagen, P., \& Marshall, D. (2015). Interest group success in the European Union: When (and why) does business lose? Comparative Political Studies, 48(8), 951-983.

Dür, A., \& Mateo, G. (2012). Who lobbies the European Union? National interest groups in a multilevel polity. Journal of European Public Policy, 19(7), 969-987.

Dür, A., \& Mateo, G. (2013). Gaining access or going public? Interest group strategies in five European countries. European Journal of Political Research, 52(5), 660-686.

Dür, A., \& Mateo, G. (2014). Public opinion and interest group influence: How citizen groups derailed the Anti-Counterfeiting Trade Agreement. Journal of European Public Policy, 21(8), 1199-1217.

Eising, R. (2004). Multilevel governance and business in- terests in the European Union. Governance, 17(2), 211-245.

Eising, R. (2007). Institutional context, organizational resources and strategic choices explaining interest group access in the European Union. European Union Politics, 8(3), 329-362.

Gilens, M., \& Page, B. I. (2014). Testing theories of American politics: Elites, interest groups, and average citizens. Perspectives on Politics, 12(3), 564-581.

Gray, V., \& Lowery, D. (1996). A niche theory of interest representation. The Journal of Politics, 58(1), 91-111.

Halpin, D. (2011). Explaining policy bandwagons: Organized interest mobilization and cascades of attention. Governance, 24(2), 205-230.

Halpin, D., \& Jordan, G. (2009). Interpreting environments: Interest group response to population ecology pressures. British Journal of Political Science, 39(2), 243-265.

Heaney, M. (2004). Outside the issue niche the multidimensionality of interest group identity. American Politics Research, 32(6), 611-651.

Helbling, M., Hoeglinger, D., \& Wüest, B. (2010). How political parties frame European integration. European Journal of Political Research, 49(4), 496-521.

Hix, S., \& Høyland, B. (2013). Empowerment of the European Parliament. Annual Review of Political Science, 16, 171-189.

Hutter, S., \& Grande, E. (2014). Politicizing Europe in the national electoral arena: A comparative analysis of five west European countries, 1970-2010. Journal of Common Market Studies, 52(5), 1002-1018.

Klüver, H. (2011). The contextual nature of lobbying: Explaining lobbying success in the European Union. European Union Politics, 12(4), 483-506.

Klüver, H., Braun, C., \& Beyers, J. (2015). Legislative lobbying in context: Towards a conceptual framework of interest group lobbying in the European Union. Journal of European Public Policy, 22(4), 447-461.

Koopmans, R. (2007). Who inhabits the European public sphere? Winners and losers, supporters and opponents in Europeanised political debates. European Journal of Political Research, 46(2), 183-210.

LaPira, T., Thomas, H., III, \& Baumgartner, R., (2014). The two worlds of lobbying: Washington lobbyists in the core and on the periphery. Interest Groups \& Advocacy, 3(3), 219-245.

Lindgren, K.-O., \& Persson, T. (2008). The structure of conflict over EU chemicals policy. European Union Politics, 9(1), 31-58.

Lowery, D. (2007). Why do organized interests lobby? A multi-goal, multi-context theory of lobbying. Polity, 39(1), 29-54.

Mahoney, C. (2004). The power of institutions state and interest group activity in the European Union. European Union Politics, 5(4), 441-466.

Mahoney, C. (2008). Brussels versus the beltway. Advocacy in the United States and the European Union. Washington, DC: Georgetown University Press. 
Mattila, M. (2009). Roll call analysis of voting in the European Union Council of Ministers after the 2004 enlargement. European Journal of Political Research, 48(6), 840-857.

Olson, M. (1965). The logic of collective action. Cambridge, MA: Harvard University Press.
Schattschneider, E. (1960). The semi-sovereign people: A realist's view of democracy in America. New York, NY: Holt, Rinehart and Winston.

Thomson, R., Boerefijn, J., \& Stokman, F. (2004). Actor alignments in European Union decision making. European Journal of Political Research, 43(2), 237-261.

\section{About the Authors}
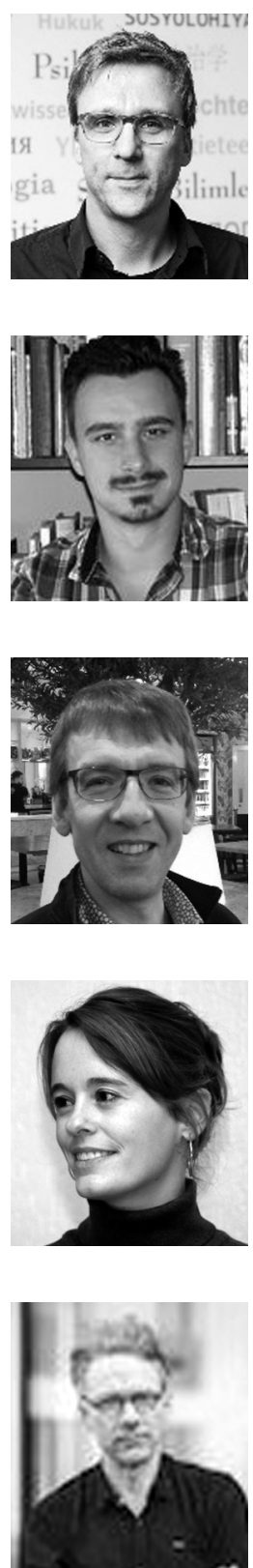

Arndt Wonka is Senior Researcher at the University of Bremen's Bremen International Graduate School of Social Sciences (BIGSSS). His current research focusses on the mobilization and contestation of interest groups and political parties mostly in the EU's multilevel institutional context and in EU policymaking. He has also published on the European Commission and EU regulatory agencies and their role in EU politics.

Iskander De Bruycker is a Postdoctoral Research Fellow for the Research Foundation Flanders, currently residing at the European University Institute in Florence. He was previously affiliated to the University of Amsterdam and the University of Aarhus and recently received support from the Research Foundation Flanders for his project on how public opinion and lobbying influence EU policy decisions. Iskander's research activities lie in the fields of European public policy, political communication, and interest group politics.

Dirk De Bièvre is Associate Professor in the Department of Political Science at the University of Antwerp. He is especially interested in the political economy of the EU and international trade relations as well as the role of international institutions. He is the author of The Trade Policy of the European Union (with S. Gstöhl; Palgrave, 2018) and of Judicial Politics and International Cooperation (with A. Poletti; ECPR Press, 2016).

Caelesta Braun is Associate Professor at the Institute of Public Administration at Leiden University. Her research interests include regulatory governance, interest group politics and public decision making. She is currently the principal investigator of a research project on regulatory capture in multi-level governance systems funded by The Netherlands Organisation for Scientific Research. She is particularly interested in interest group engagement vis-a-vis public agencies.

Jan Beyers is Professor of Political Science and Francqui Research Professor at the University of Antwerp. His research focuses on organized interest representation, advocacy and policy responsiveness, political organizations and institutions. He has widely published on these topics in major journals such as European Journal of Political Research, Governance, and Journal of European Public Policy. At this moment, he is co-editor of the recently established journal Interest Groups \& Advocacy. 